\title{
Quality Improvement on Optical Fiber Coloring Process using Fault Tree Analysis and Failure Mode and Effect Analysis
}

\author{
Rerandre Sofyan Masykur $^{1}$, Adriyani Oktora ${ }^{2}$ \\ ${ }^{1-2}$ Industrial Engineering Department, Faculty of Engineering, University of Mercu Buana \\ Jl. Raya Meruya Selatan, Kembangan, \\ Jakarta 11650 Indonesia
}

\begin{abstract}
This study aims to identify the types and causes of defect, and also provide recommendations for improvements to reduce and prevent defect in the optical fiber coloring process. The fault Tree Analysis (FTA) Method is used in this study to identify the relationship between the causative factors and the shape of the fault tree. The Failure Mode and Effect Analysis (FMEA) method is used to analyze the causal factors identified by the FTA method. The results of the FTA Method show that the dominant defect type that occurs in the optical fiber coloring process is stripped fiber. The percentage of striped fiber defects is $36 \%$ which caused by machine, material, and method factors. The final result of the Failure Mode and Effect Analysis (FMEA) method is the highest Risk Priority Number (RPN) value, namely clogged ink housings (dies) with an RPN value of 294.
\end{abstract}

Key Words: Fault Tree Analysis, Quality, Improvement, Failure Mode and Effect Analysis, Optical Fiber

\section{INTRODUCTION}

Quality is conformance to requirement, which is what is required or standardized [16]. A product has quality if it conforms to predetermined quality standards. Quality standards include raw materials, production processes and finished products. One of the effective quality improvement models is to identify possible product failures that have the potential to disappoint customers by anticipating all stages of product design, process and function [11]. Quality in the manufacturing industry in addition to emphasizing on the products produced, must also pay attention to quality in the production process [2]. In fact, it is best if the attention to quality is not on the final product, but on the production process or products that are still in the process (work in process), so that if there are known defects or errors, they can still be corrected.

PT. Jembo Cable Company is a company engaged in the manufacturing industry, which produces various types of cables. Fiber optic cable is one of the various types of products produced by PT. Jembo Cable Company and is one of the products that are produced in large quantities. Quality is one of the important factors that must be maintained by PT. Jembo Cable Company to maintain the competitiveness and loyalty of their customers. The production process system has been implemented properly, but in fact there are still defects in the products that are not in accordance with predetermined quality standards.

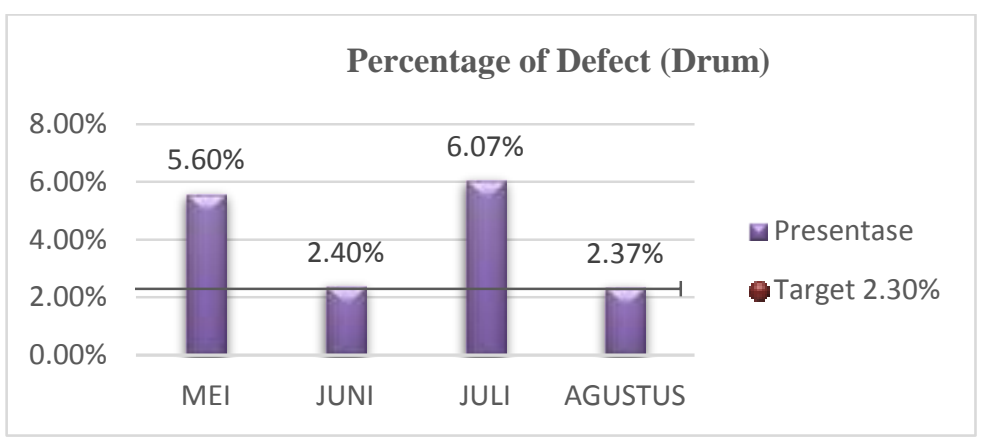

Figure 1. Graph of the Defects Percentage of the Fiber Optic Coloring Process

Figure 1 shows that In May 2020 - August 2020 the Fiber Optic Coloring Process produced 7,161 drums with an average of 50,400 Meters per drum. Of the 7,161 drums produced, there were defective products with a defective number of 292 drums, this 
resulted in a longer repair time. The quality of the resulting product must be maintained and improved so that the company is able to compete with other companies and maintain consumer confidence in the company's products. Good product quality and according to standards is very important for the sustainability of the company.

\section{LITERATURE REVIEW}

\subsection{Fault Tree Analysis (FTA)}

Fault Tree Analysis (FTA) is a technique that provides a systematic explanation of the combination of events that may occur in a system that results in damage. The failure tree analysis is a deductive analysis, where an event is caused by a previous event. Previous events are caused by further other events, component failure or operator (human) failure. The causes of each failure were further analyzed so that it arrived at the basic event conditions. The top event of the failure tree indicates an unwanted event or condition. The Top Event must first be identified, then events that directly cause the Top Event to be identified and linked to the Top Event using a logical relationship [11]. The Fault Tree Analysis (FTA) method is a technique used to identify risks that play a role in identifying risks that contribute to failure [9]. This method is carried out with a top down approach, which begins with the assumption of failure from the top event (Top Event) and then details the causes of a Top Event to a basic failure (root cause). Logic gates describe conditions that trigger failure, both single conditions and a collection of various conditions. The construction of a Fault Tree Analysis (FTA) includes logic gates, namely AND gates and OR gates. A fault tree illustrates the state of the system components (basic events) and the relationship between the basic event and the top event represents the connection in the logic gate. The FTA steps are as follows:

1. Identification of the Top Level Event

At this stage, the type of damage that has occurred (undesired event) is identified to identify system errors. Understanding of the system is done by learning all the information about the system and its scope.

2. Create a Error Tree Diagram

The fault tree diagram shows how top level events can appear on the network

3. Analyze the fault tree

Error tree analysis is used to obtain clear information on a system and the necessary improvements.

\subsection{Failure Mode an Effect Analysis (FMEA)}

Failure Modes and Effects Analysis (FMEA) is a methodology used to evaluate failures that occur in a system, design, process, or service. Identification of potential failures is carried out by weighting the value or score of each failure mode based on the level of occurrence (occurrence), severity (severity), and level of detection (detection) [10]. FMEA is a powerful preventive method for risk management, which aims to eliminate the potential failures associated with individual machine components. FMEA is used to identify potential failure modes, determine their effect on product manufacturing, and suggest actions to avoid failure (Suresh et al., 2017). Failure Mode and Effect Analysis (FMEA) is a systematic method for identifying and carrying out problem prevention solutions to the processes and products to be carried out. FMEA focuses on prevention, increase work safety, increase customer satisfaction. FMEA is divided into FMEA design and process FMEA [15]. In the process of making a product, failure can occur, which is called failure mode. Each failure mode has a potential cause and effect arising from that failure. In other words, each potential effect has its own risks. FMEA process technique is a way to identify failures, effects and risks of processes or products and solutions to reduce these failures. The risk of failure and its effects is determined by the following three factors [8]:

\section{[1] Severity}

Severity is a matter of identifying the potential impact of a failure by ranking failures according to their consequences. The level of effect of failure (severity) has a ranking of 1 to 10. For Rank 1 is the lowest seriousness level (low risk) and rank 10 is the highest seriousness level (high risk).

[2] Occurrence

Occurrence it is probable that such causes could occur and result in a form of failure over the life of the product. The occurance ranking is ranked 1-10. For rank 1 is a low incidence rate (not often) and ranking 10 is a high incidence rate (often)

[3] Detection

Detection is a method (procedure), test, or analysis to prevent failure of a service, process, or customer. In determining the Detection ranking, there is a ranking of 1-10. Rank 1 is the level of control that can detect failure (always can) and ranking 10 is the level of control that cannot detect failure.

FMEA recognizes what is called a Risk Priority Number (RPN), which is a value that will describe which areas need to be our priority for improvement. RPN is measured based on rating considerations from the three factors above, namely Severity, Occurrence, and Detection. 


\section{RESEARCH METHODOLOGY}

Figure 2 shows that in this study, researchers used literature and expert interviews to identify what types of defects occur in the optical fiber coloring process. This research involved 3 experts in the field of production. Respondents' positions and years of service indicate their expertise. Then the researchers designed the FTA model, so that it can be known what factors cause defects in the product. The identified factors then become input for the FMEA method. the result of FMEA is in the form of RPN value which will be the basis for proposed improvements to be made, to improve product quality.

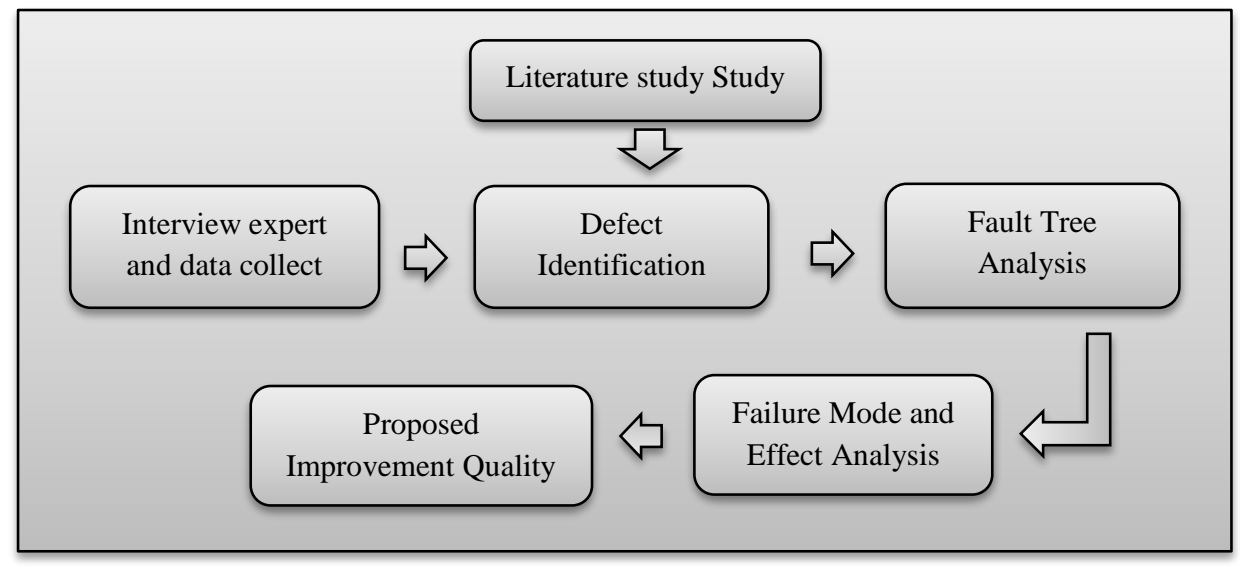

Figure 2. Research Steps Using FTA and FMEA

\section{RESULT AND DISCUSSION}

\subsection{Defect Identification}

Data collection carried out in this study sourced from PT. Jembo Cable Company. The data taken is in the form of production data and defect data that occurred in the Optical Fiber Coloring Process for the period May-August 2020, as well as the Fiber Optic Coloring Process flow. Based on the results of data collection that has been done, it is known that the types of defects that occur in the optical fiber coloring process are 4 (four) types of defects, namely: Striped Fiber, Broken Fiber, Sticky Fiber and Charred Fiber. This data collection is obtained through an interview process with the Qualiy Control (QC) Department and machine operators. Direct observations in the field were also carried out by researchers to adjust secondary data obtained from the company and see actual conditions during the production process. Figure 3 shows the largest to the smallest types of defects are as follows:

1.Defect type of Striped Fiber with a defect percentage of $36.00 \%$

2. Types of sticky fiber defects with a defect percentage of $22.90 \%$

3. types of broken Fiber defects with a defect percentage of $20.90 \%$

4. defective type of Charred Fiber with a defect percentage of $20.20 \%$.

Figure 3 shows that the most dominant type of defect is Striped Fiber defect with a defect percentage of $36.00 \%$. So that the main repairs are focused on the Fiber Striped defect. 


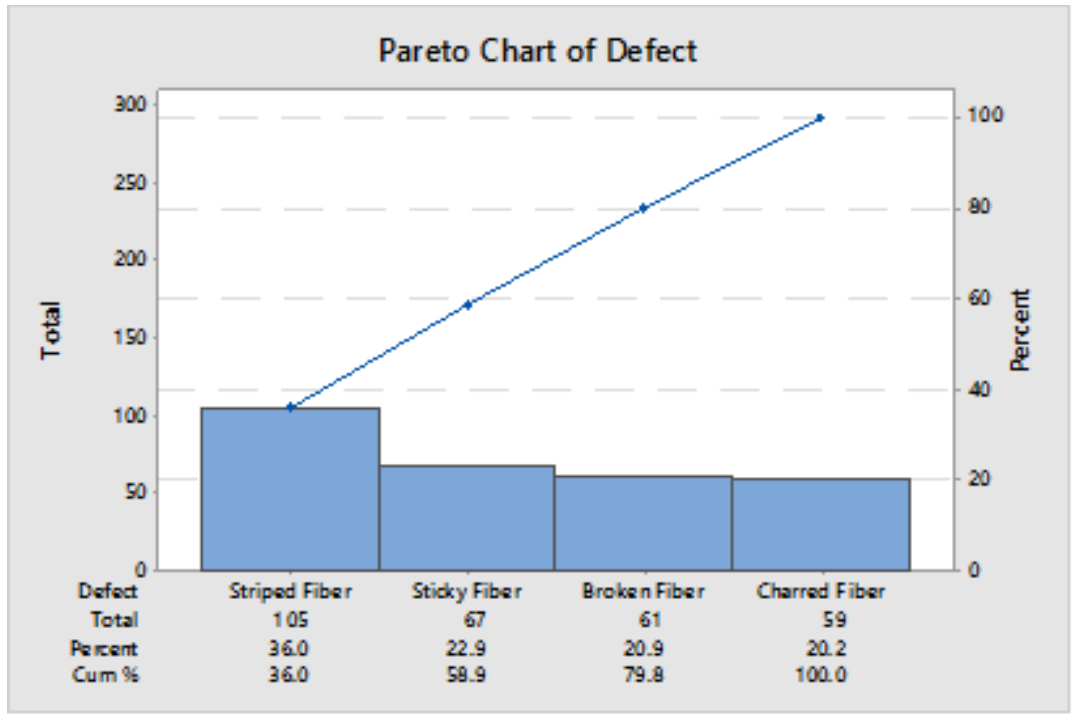

Figure 3.Pareto Chart Of Defect

\subsection{Fault Tree Model}

FTA is used to determine what factors cause the defect of striped fibers. From the results of the analysis that has been made using Fault Tree Analysis (FTA) based on Figure 4. The factors that cause the occurrence of striped fiber defects in the optical fiber coloring process are the factors of Material, Machine, and Methods. These factors are as follows:

1. Machine factor

The machine factor is one of the most important factors, with the machine really helps the smooth running of the production process. However, with a procedure or method that is not done properly, the machine cannot produce the output according to what has been determined. This striped fiber defect is influenced by several reasons, including: a) The staining result is less than perfect, this happens because the Dies / ink house is clogged and the ink mixing is not evenly distributed. b) Incomplete drying, this happens because of the lack of heat generated by the UV Tube

2. Material Factors

The use of good quality materials determines the results of a quality product. So material selection is an important factor in the production process. This striped fiber defect is influenced by several reasons, including material quality that is not standard, coloring ink that has expired which makes the quality of the material used does not meet standards

3. Factor Methods

The method used in the production process plan determines the results and also the quality of the products produced. Method errors can be a loss for the company. This is what causes striped fiber defects where the cause is incorrect machine setting that is, there is still a lack of nitrogen needed when starting loading 


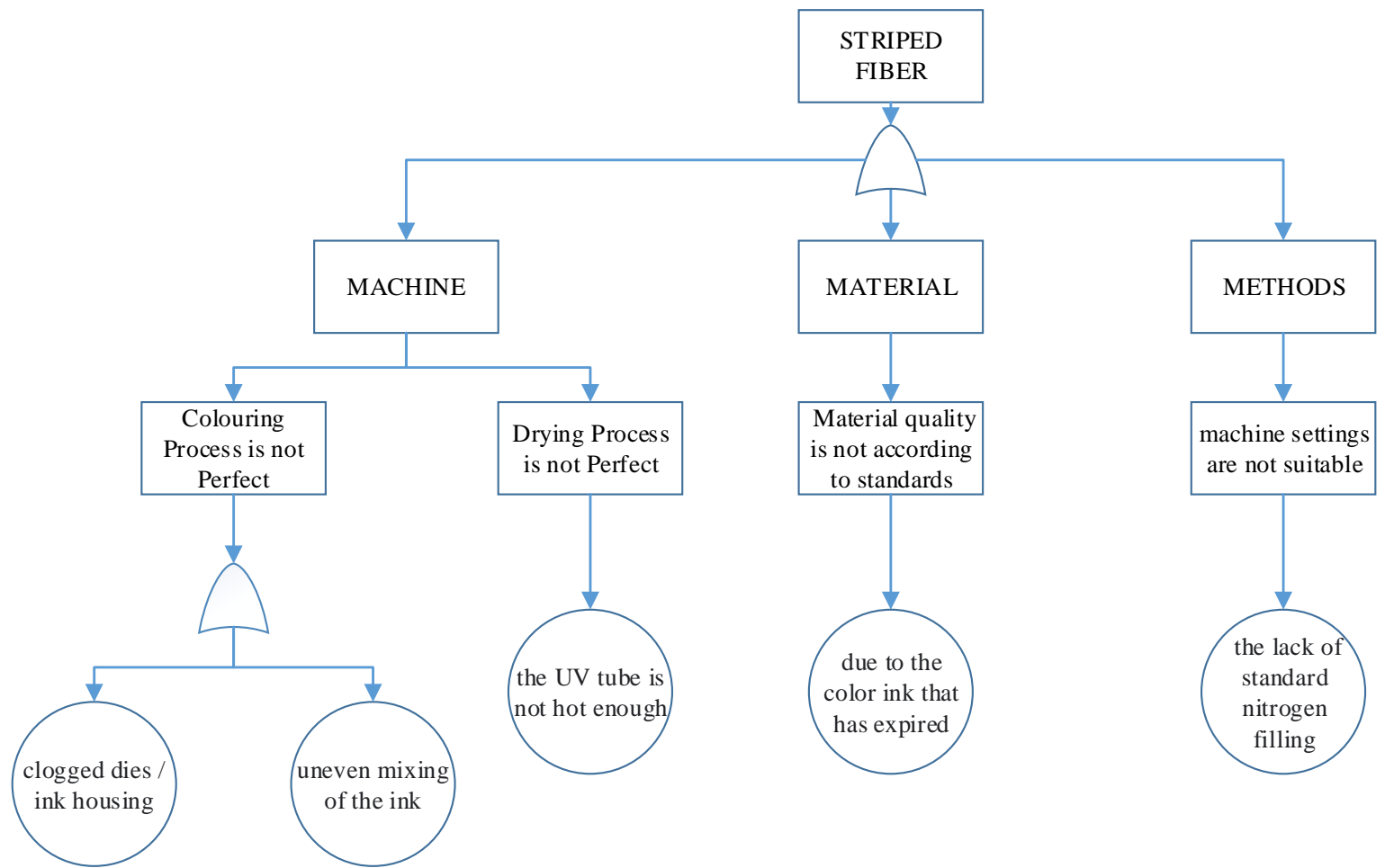

Figure 4. Fault Tree Model

\subsection{FMEA}

Failure Mode and Effect Analysis (FMEA) functions to provide weighting for the Severity, Occurance, and Detection values based on the potential effects of failure and causes of failure, then the results are obtained for the Risk Priority Number (RPN) value. The RPN value is obtained from the results of the assessment carried out by the company who is an expert / expert selected to fill out the FMEA questionnaire. Questionnaire fillers are people who understand and have a position in the company's organizational structure. The value of Severity $(\mathrm{S})$ is obtained from data on the number of production and disabilities, then an interview is conducted to find out the weight of the value that corresponds to the impact of the disability that occurs in the Coloring Process, by ranking failures according to the consequences. The Occurance $(\mathrm{O})$ value is obtained by interviewing the company by ranking it based on the average incidence of each of the factors that cause disability in the Coloring Process. The Detection value (D) is obtained by conducting interviews with the company based on the level of control in the Coloring Process which is able to detect failure or not. Table 1 shows the RPN values generated for each cause of disability.

Table 1. Failure Mode and Effect Analysis (FMEA)

\begin{tabular}{|c|c|c|c|c|c|c|c|c|}
\hline $\begin{array}{l}\text { Failure } \\
\text { Mode }\end{array}$ & $\begin{array}{c}\text { Effect of } \\
\text { Failure Mode }\end{array}$ & Factor & $\begin{array}{c}\text { Cause of Failure } \\
\text { Mode }\end{array}$ & Severity & Occurance & Detectio & $\begin{array}{c}\text { Risk } \\
\text { Priority } \\
\text { Number }\end{array}$ & $\begin{array}{c}\text { Rank } \\
\text { Of } \\
\text { RPN }\end{array}$ \\
\hline \multirow{5}{*}{$\begin{array}{l}\text { Striped } \\
\text { Fiber }\end{array}$} & \multirow{5}{*}{$\begin{array}{l}\text { The product } \\
\text { cannot continue } \\
\text { to the next } \\
\text { process and } \\
\text { requires a } \\
\text { longer repair } \\
\text { time }\end{array}$} & \multirow{3}{*}{ Machine } & $\begin{array}{l}\text { Uneven Mixing } \\
\text { of The Ink }\end{array}$ & 5 & 6 & 5 & 150 & 2 \\
\hline & & & $\begin{array}{l}\text { Clogged } \\
\text { Dies/ink } \\
\text { Housing }\end{array}$ & 7 & 7 & 6 & 294 & 1 \\
\hline & & & $\begin{array}{l}\text { The UV tube is } \\
\text { not hot enough }\end{array}$ & 5 & 5 & 3 & 75 & 5 \\
\hline & & Material & $\begin{array}{l}\text { The colouring } \\
\text { ink that has } \\
\text { expired }\end{array}$ & 5 & 4 & 4 & 80 & 4 \\
\hline & & Methods & $\begin{array}{c}\text { The lack of } \\
\text { standard nitrogen } \\
\text { filling }\end{array}$ & 6 & 5 & 4 & 120 & 3 \\
\hline
\end{tabular}


In Table 1, we can see the results of the calculation of the Risk Priority Number (RPN), and it is known that the cause of the highest Striped Fiber failure in the Optical Fiber Coloring Process is the Clogged Dies Section with an RPN value of 294.

\subsection{Proposed Improvement}

The proposed plan to improve product quality to reduce striped fiber defects in the coloring process will be carried out using the $5 \mathrm{~W}+1 \mathrm{H}$ method. This method will identify each cause of the failure mode that exists, by clarifying what the repair plan is, why it needs fixing, where to fix it, and who is fixing it and how to fix it. Table 2 shows the proposed improvements that can be done to reduce the possibility of fiber defects that occur. This proposal is expected to improve product quality periodically and gradually in the future.

Table 2. $5 \mathrm{~W}+\mathbf{1 H}$

\begin{tabular}{|c|c|c|c|c|c|c|c|}
\hline $\begin{array}{c}\text { Types } \\
\text { of } \\
\text { Defects }\end{array}$ & $\begin{array}{l}\text { Cause of } \\
\text { failure }\end{array}$ & $\begin{array}{l}\text { What (What is the } \\
\text { plan for repair?) }\end{array}$ & $\begin{array}{c}\text { Why (Why is } \\
\text { it necessary } \\
\text { to repair?) }\end{array}$ & $\begin{array}{c}\text { Where (Where } \\
\text { is the repair } \\
\text { done?) }\end{array}$ & $\begin{array}{c}\text { When (When } \\
\text { was the repair } \\
\text { done?) }\end{array}$ & $\begin{array}{l}\text { Who (Who } \\
\text { made the } \\
\text { repair?) }\end{array}$ & $\begin{array}{l}\text { How (How did the } \\
\text { repair be made?) }\end{array}$ \\
\hline & $\begin{array}{c}\text { Dies } \\
\text { Clogged }\end{array}$ & $\begin{array}{l}\text { Perform routine } \\
\text { cleaning on the } \\
\text { Dies soaked in } \\
\text { thinner }\end{array}$ & $\begin{array}{l}\text { To minimize } \\
\text { striped fiber } \\
\text { defects in } \\
\text { theprocess } \\
\text { coloring }\end{array}$ & $\begin{array}{l}\text { Cleaning is } \\
\text { carried out on } \\
\text { the ink bottle } \\
\text { tubes, hoses } \\
\text { and dies } \\
\text { housing. }\end{array}$ & $\begin{array}{l}\text { Every } 400 \mathrm{~km} \\
\text { of the process } \\
\text { or when the } \\
\text { color change } \\
\text { is done }\end{array}$ & $\begin{array}{l}\text { machine } \\
\text { operator in } \\
\text { the process } \\
\text { coloring }\end{array}$ & $\begin{array}{l}\text { operator performs } \\
\text { cleaning Dies with } \\
\text { thinner immersed in } \\
\text { the ink bottle tube, } \\
\text { hose and die } \\
\text { housing every } 400 \\
\text { km of the process or } \\
\text { When changing } \\
\text { colors. }\end{array}$ \\
\hline $\begin{array}{l}\text { Striped } \\
\text { Fiber }\end{array}$ & $\begin{array}{l}\text { stirring } \\
\text { the ink } \\
\text { unevenly }\end{array}$ & $\begin{array}{l}\text { Adding speed and } \\
\text { time to the ink } \\
\text { mixing machine } \\
\text { or purchasing an } \\
\text { ink mixing } \\
\text { machine with } \\
\text { better specs so }\end{array}$ & $\begin{array}{l}\text { that the ink } \\
\text { and oil can be } \\
\text { blended } \\
\text { evenly }\end{array}$ & $\begin{array}{l}\text { In theProcess } \\
\text { area Coloring }\end{array}$ & $\begin{array}{l}\text { Before the } \\
\text { production } \\
\text { process starts }\end{array}$ & $\begin{array}{l}\text { Machine } \\
\text { operator in } \\
\text { the } \\
\text { coloring } \\
\text { process }\end{array}$ & $\begin{array}{l}\text { Operator add speed } \\
\text { and time to the } \\
\text { mixing machine or } \\
\text { apply for the } \\
\text { purchase of an ink } \\
\text { mixer with better } \\
\text { spec }\end{array}$ \\
\hline
\end{tabular}

\section{CONCLUSION}

Based on the results of research conducted on the Fiber Optic Coloring Process, the most dominant type of defect in the Optical Fiber Coloring Process during the period May 2020 - August 2020, is a type of striped fiber defect with a defect percentage of $36.00 \%$ of the 4 types of defects that occur. The causes of the Striped Fiber defect are:Machine factor (clogged Dies / Ink House, uneven ink stirring, and less hot UV tube), Material factor (Ink dye used has expired), Factor Methods (Nitrogen filling is still lacking). Proposals for improvements given to overcome the occurrence of striped fiber defects based are perform routine cleaning on Dies using thinner on the ink bottle tube, hose and Dies house every $400 \mathrm{~km}$ of the process or when doing a color change, adding speed and time to an ink mixer or proposing a purchase of an ink mixer with better specifications, routinely check the nitrogen tube every time it starts loading to ensure that nitrogen needs are up to the standard, make an agreement with the dye ink supplier to send the material according to the required standard and timeframe, as well as double-check when the material arrives so that it is expected that in purchasing dye ink to get the best quality possible, make a checklist of the lifetime of UV lamp tools to quickly detect if the UV lamp has decreased performance, so that it is replaced as soon as possible by the maintenance department according to its lifetime so that the heat generated can be better. 


\section{REFERENCES}

1. Ariani, D. W. (1999). Manajemen Kualitas. Yogyakarta: Universitas Atmajaya.

2. Ariani, D. W. (2004). Pengendalian Kualitas Statistik. Yogyakarta: Andi.

3. Assauri, S. (2008). Manajemen Produksi dan Operasi. Jakarta: Lembaga Penerbit Fakultas Ekonomi Universitas Indonesia.

4. Bakhtiar, S., Tahir, S., \& Hasni, R. A. (2013). Analisa Pengendalian Kualitas Dengan Menggunakan Metode Statistical Quality Control (SQC). Malikussaleh Industrial Engineering Journal, Vol.2(No.1), p. 29-36.

5. Claxton, K., \& Campbell-Allen, N. M. (2017). Failure modes effects analysis (FMEA) for review of a diagnostic genetic laboratory process. International Journal of Quality \& Reliability Management, Vol.34(2), p. 266-277.

6. Fatima, S., Beg, D. M. R., \& Siddiqui, S. (2013). Improving Software Quality Using FMEA and FTA Defect Prevention Techniques in Design Phase. International Journal of Computer Science and Information Technologies, Vol.4(1), p. 178-182.

7. Gaspersz, V. (2005). Total Quality Management. Jakarta: PT. Gramedia Pustaka Utama.

8. Ghivaris, G. Al, Soemadi, K., \& Desrianty, A. (2015). Usulan Perbaikan Kualitas Proses Produksi Rudder Tiller Di PT. Pindad Bandung Menggunakan FMEA dan FTA. Jurnal Online Institut Teknologi Nasional, Vol.03(04), p. 73-84.

9. Hanif, R. Y., Rukmi, H. S., \& Susanty, S. (2015). Perbaikan Kualitas Produk Keraton Luxury Di PT. X Dengan Menggunakan Metode Failure Mode and Effect Analysis (FMEA) dan Fault Tree Analysis (FTA). Jurnal Online Institut Teknologi Nasional, Vol.03(03), p. 137-147.

10. Hasbullah, H., Kholil, M., \& Santoso, D. A. (2017). Analisis Kegagalan Proses Insulasi Pada Produksi Automotive Wires (AW) Dengan Metode Failure Mode and Effect Analysis (FMEA) Pada PT JLC. SINERGI, 21(3), p. $193-203$.

11. Hidayat, I., \& Pratiwi, S. E. (2013). Analisa Faktor Penyebab Kegagalan Mesin Grinder Pada Proses Produksi Plastic Film Di PT. Mutiara Hexagon. SINERGI, Vol.17(3), p. 255-261.

12. Kartika, H. (2013). Analisis Pengendalian Kualitas Produk CPE FILM Dengan Metode Statistical Process Control Pada PT. MSI. Jurnal Ilmiah Teknik Industri, Vol. 1(No.1), p. 50 - 58.

13. Kartika, W. Y., Harsono, A., \& Permata, G. (2016). Usulan Perbaikan Produk Cacat Menggunakan Metode Fault Mode and Effect Analysis dan Fault Tree Analysis Pada PT. Sygma Examedia Arkanleema. Jurnal Online Institut Teknologi Nasional, Vol.4(01), p. 345-356.

14. Krisnaningsih, E., \& Hadi, F. (2020). Strategi Mengurangi Produk Cacat Pada Pengecatan BOILER STEEL STRUCTURE Dengan Metode Six Sigma Di PT. CIGADING HABEAM CENTER. Jurnal InTent, Vol.3(No.1), p. 11-24.

15. McDermott, R. (2009). The Basics of FMEA (Edisi 2.). USA: CRC Press.

16. Nasution, M. N. (2015). Manajemen Mutu Terpadu (Total Quality Management). Jakarta: Ghalia Indonesia.

17. Nugroho, R. E., Marwanto, A., \& Hasibuan, S. (2017). Reduce Product Defect in Stainless Steel Production Using Yield Management Method and PDCA. International Journal of New Technology and Research, Vol.3(11), p. 39-46.

18. Parsana, T. S., \& Patel, M. T. (2014). A Case Study: A Process FMEA Tool to Enhance Quality and Efficiency of Manufacturing Industry. Bonfring International Journal of Industrial Engineering and Management Science, Vol.4(3), p.145152.

19. Purnomo, H. (2007). Pengantar Teknik Industri. Yogyakarta: Graha Ilmu.

20. Rachman, A., Adianto, H., \& Liansari, G. P. (2016). Perbaikan Kualitas Produk Ubin Semen Menggunakan Metode Failure Mode and Effect Analysis dan Failure Tree Analysis Di Institusi Keramik. Jurnal Online Institut Teknologi Nasional, Vol.4(02), p. 24-35.

21. Suresh, A., Pramod, V. K., \& Pramod, V. R. (2017). Failure Mode Effect Analysis in a Frying Pan Manufacturing Industry. International Research Journal of Engineering and Technology (IRJET), Vol.04(08), p. 1183-1189.

22. Syukron, A., \& Kholil, M. (2013). Six Sigma : Quality for Business Improvement. Yogyakarta: Graha Ilmu.

23. Syukron, A., \& Kholil, M. (2014). Pengantar Teknik Industri. Yogyakarta: Graha Ilmu.

24. Tannady, H. (2015). Pengendalian Kualitas. Yogyakarta: Graha Ilmu.

25. Ulkhaq, M. M., Pramono, S. N. W., \& Halim, R. (2017). Aplikasi Seven Tools Untuk Mengurangi Cacat Produk Pada Mesin Communite Di PT. MASSCOM GRAPHY, SEMARANG. PASTI, Vol.11(No.3), p. 220-230. 